\title{
Impact of Social Media on Consumer Purchasing Behaviour in Sarawak
}

Ngu Shan Ying, Rossazana Ab-Rahim, Khairil-Anuar Mohd-Kamal

To Link this Article: http://dx.doi.org/10.6007/IJARBSS/v11-i5/9935

DOI:10.6007/IJARBSS/v11-i5/9935

Received: 18 March 2021, Revised: 20 April 2021, Accepted: 04 May 2021

Published Online: 15 May 2021

In-Text Citation: (Ying et al., 2021)

To Cite this Article: Ying, N. S., Ab-Rahim, R., \& Mohd-Kamal, K.-A. (2021). Impact of Social Media on Consumer Purchasing Behaviour in Sarawak. International Journal of Academic Research in Business and Social

Sciences, 11(5), 367-375.

\section{Copyright: (c) 2021 The Author(s)}

Published by Human Resource Management Academic Research Society (www.hrmars.com)

This article is published under the Creative Commons Attribution (CC BY 4.0) license. Anyone may reproduce, distribute, translate and create derivative works of this article (for both commercial and non-commercial purposes), subject to full attribution to the original publication and authors. The full terms of this license may be seen at: http://creativecommons.org/licences/by/4.0/legalcode

\section{Vol. 11, No. 5, 2021, Pg. 367 - 375}

Full Terms \& Conditions of access and use can be found at http://hrmars.com/index.php/pages/detail/publication-ethics 


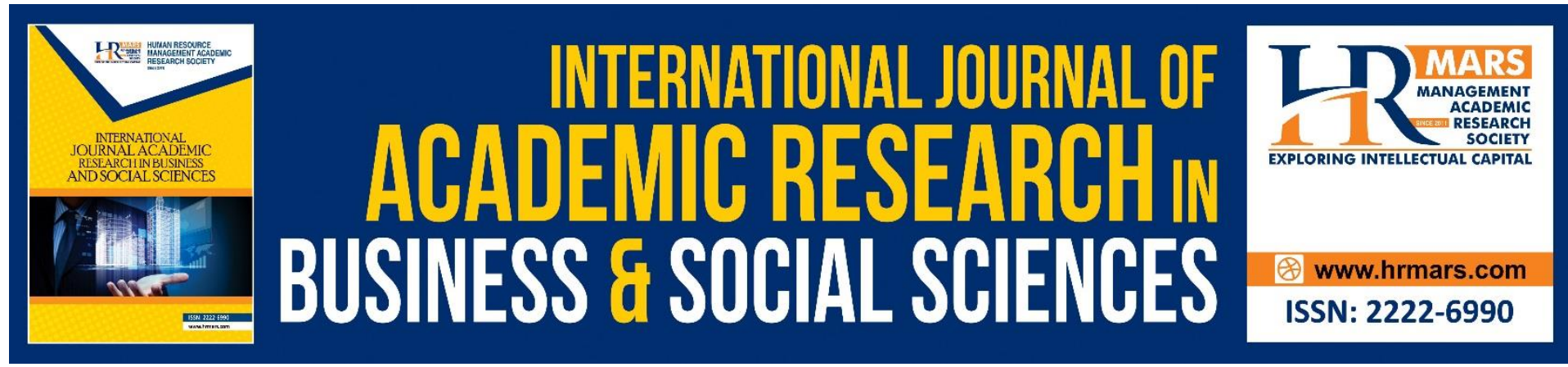

\title{
Impact of Social Media on Consumer Purchasing Behaviour in Sarawak
}

\author{
Ngu Shan Ying, Rossazana Ab-Rahim, Khairil-Anuar Mohd- \\ Kamal
}

Faculty of Economics and Business, Universiti Malaysia Sarawak, Malaysia

Email: rossazana@gmail.com

\begin{abstract}
Due to the disclosure of Web 2.0, the traditional marketing methods have undergone tremendous changes which brought a new era to marketers in the background of social media. The social media are changing as well as influencing the way consumers behave. Hence, this study aims to investigate the factors that influences the consumer purchasing behaviour in Kuching, Sarawak, and to understand which factor has the greatest impact on consumer that purchase through social media sites. Primary data via questionnaire is employed to investigate the impact of social media on purchasing behaviour of consumers in Kuching, Sarawak. It will be interesting to identify the factors influence the most for purchasing behaviour of consumers on social media. There are four factors, namely personal, social, psychological, and cultural factors assessed in this study. The methodology techniques employed in this study are frequency analysis, descriptive analysis, Pearson's correlation analysis, and multiple regression analysis. Based on the results of analysis, psychological factors is found to be the most influential factor for consumers purchasing behaviour in Kuching, Sarawak. The results of this study imply businesses should utilise social media and involve in online platform to have a better understanding on consumers purchasing behaviour and to tap the market share. Keywords: Consumers purchasing behaviour, Cultural, Personal, Psychological, Social
\end{abstract}

\section{Introduction}

People have undergone a fundamental change in the way they operate business and their interaction with each other year after year. According to Choo (2013), due to the disclosure of Web 2.0, the traditional marketing approaches have undergone tremendous changes which brought a new era to marketers. Obviously, the number of internet users is increasing nowadays, and research show that in 2018, there are $87.4 \%$ of internet users in Malaysia (Malaysian Communications and Multimedia Commission, 2018).

The existence of social media is considered as one of the latest and most influential electronic marketing tools in the present time. Since the introduction of social media, people have turned to social media for personal communications. In addition to individual usage, social media brings many benefits to businesses. Social media has attracted different industries because of the advantages it could bring to the businesses. As compared with the other traditional communication channels, social media has induced many industry leaders to 
join social media, such as Facebook, Twitter, Instagram, and others, to achieve success in online platforms. People are using social media for company marketing to promote brands products as well as to maintain relationship with customers. The organizations in Malaysia have also started using social media as it has impact on the performance and growth of businesses in the same way. Therefore, this shows that the usage of social media in Malaysian organizations is booming as many organizations have begun to realize the importance of social media in improving their business performance.

In addition, social media is changing and affecting the way consumers behave. Consumer behaviour is a diversified and dynamic process which affected by four main factors, which are personal, social, psychological, and cultural factors. Over the past few decades, the shopping method of people has changed dramatically, from shopping at physical stores to shopping over the Internet using different type of social media platforms (Toomey \& Wysocki, 2009). Thus, it is clear that to succeed in a business, marketers must understand consumer buying behaviour and how the social media influence purchasing behaviour.

\section{Past Studies}

A study on factors that influencing consumer purchasing behaviour among youth's generation in Malacca has been carried out by Nur Izzati (2015). There were two objectives in this study, which is to examine factors influencing online shopping among youth and find out what influences youth to purchase online. A survey has been conducted and 150 questionnaires were distributed among youth from various universities as well as public in Malacca. According to the survey results, convenience and time saving have a significant impact and have moderate positive correlation with consumers' online purchasing behaviour.

Based on the study of Woon and Ong (2018) on the topic of influence of advertising media towards consumer purchasing behaviour in the food and beverage (F\&B) industry in Malaysia, the study is aimed to study the relationship between print service advertising, broadcast advertising, social media advertising and consumer purchasing behaviour. A quantitative cross-sectional survey approach has been applied in this study, combined with factor analysis and multiple regression analysis. For the findings of this study, the latter showed that print service advertising, broadcast advertising and social media advertising were positively related to consumer buying behaviour.

Lastly, Muniady et al. (2014) carried out a study on factors that influence purchasing behaviour of university students in Malaysia. The objective of this study is to investigate how personal factors such as lifestyle, personality, and economic situations influence the purchasing behaviour of university students in Malaysia. A quantitative method has been used and a self-administered questionnaire was distributed among university students to collect data. The findings indicate that 'personality' affects the purchasing behaviour of Malaysian university students. 


\section{Conceptual Framework}

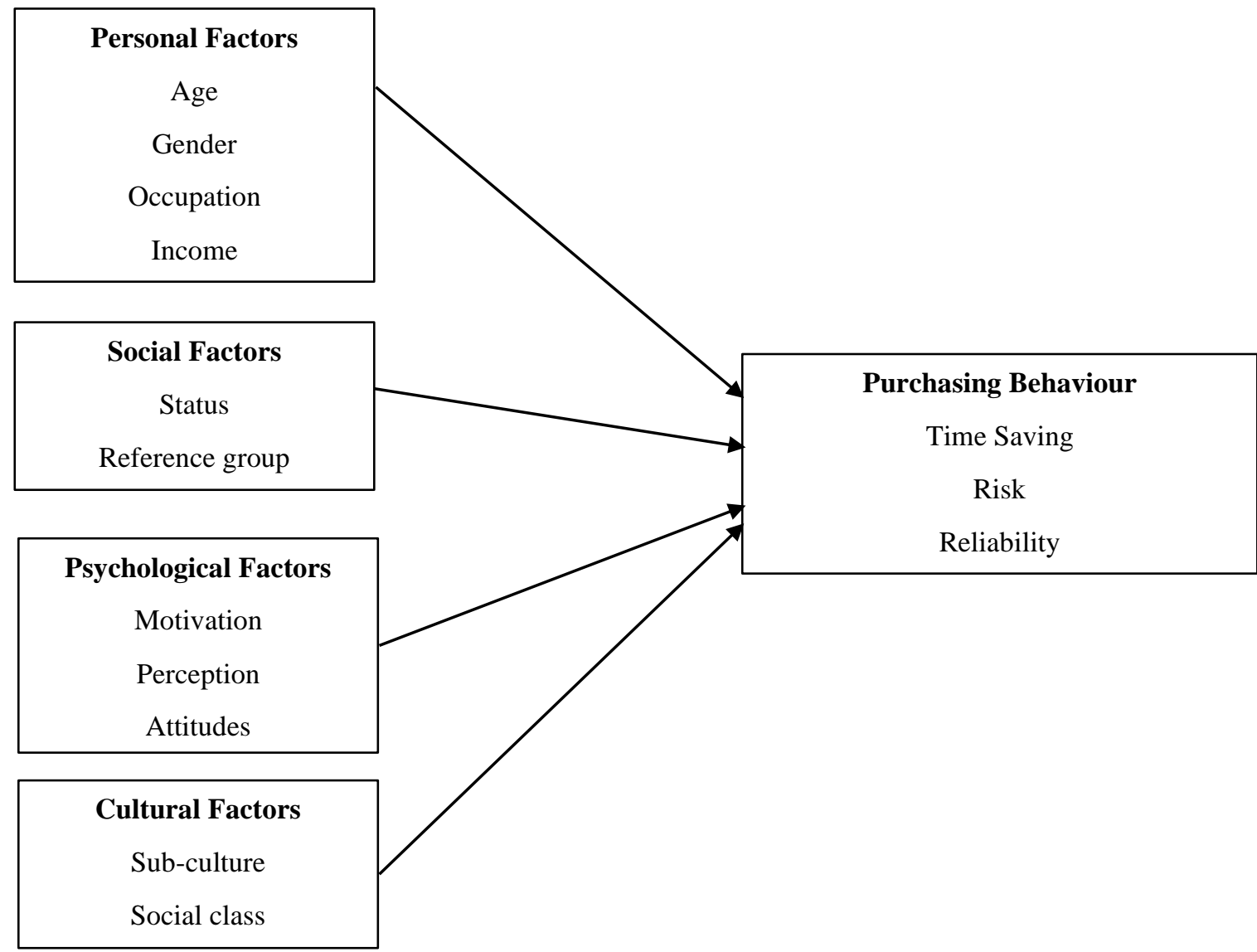

Figure 1. Conceptual Model of Factors That Influence Consumer Purchasing Behaviour

Based on the conceptual framework that has been listed in the figure above, consumer purchasing behaviour is influenced by various type of factors, which are personal factors, social factors, psychological factors, and cultural factors.

The conceptual framework above indicates the relationship between independent and dependent variables in the study. Fundamentally, the conceptual framework above indicates the basis of the entire study. The dependent variable in this study is purchasing behaviour which has been analysed to figure out the solution of the problem. Meanwhile, personal factors, social factors, psychological factors as well as cultural factors are the independent variables in this study.

The personal factors include age, gender, occupation, and income. Social factors on the other hand, consist of status and reference group. Furthermore, psychological factors comprise of motivation, perception, and attitudes. Lastly, the cultural factors consist of subculture, and social class.

\section{Description of Variables Purchasing Behaviour}

According to Lee (2000), the two factors that motivate for online purchase are convenience and saved time. Bauer (1960) mentioned that consumer behaviour can be viewed because of perceived risk faced by consumers in their economic behaviour. The risk is not the objective risk but the one that the consumer believes as being exist or absent, and how much does it perceive. In the research of Albert (2011), female respondents stated that convenience is the 
highest factor that motivates them to do purchase online, whereas male respondents considered that customer service from the dimension of reliability as well as selection is important to purchase online.

\section{Personal Factors}

Ramya and Mohamed Ali (2016) suggested that there are five determinants of consumer behaviour have been sorted out, and one of them is personal factor. Age, occupation, income, and lifestyle are the important factors that influence consumer behaviour.

\section{Social Factors}

Status, and reference group have been reviewed under the social factors in previous study. Thorstein Veblen (1899) has introduced the "conspicuous consumption" as well as "status consumption" concept under the Theory of the Leisure Class, which was the means of purchasing expensive goods and displaying them to others to show off one's wealth. In short, status consumption was described as one who purchase conspicuous goods to gain status or to be accepted by his social circle. According to Schiffman and Kanuk (2000), reference groups presents as frames of reference for individuals in their purchasing or buying decisions from the perspective of consumer behaviour. According to Moore et al. (2002), family is the most important reference group for consumers while purchasing, and the buyers are mostly influenced by their family members.

\section{Psychological Factors}

The psychological factors that defined by Smith and Rupp (2003) in Hasslinger et al. (2005) have been categorized in five parts, which are motivation, perception, personality, attitude, and emotions. The motivation is when the consumer is reasoning for incentives to engage in a specific behaviour; perception is when the consumer is interpreting information received by closing it; personality is when consumer is adapting to influence cognition; attitude is when consumer is working out for what he likes or dislikes in respect to a certain situation; and lastly, emotions is when the consumer is being affected by his or her cognitive choice without conscious effort.

\section{Cultural Factors}

A culture can be divided into subcultures on the demographics, geographic regions, ethnic and ethnic background, political beliefs, and religious beliefs. To understand the cultural differences, there are many models have been conceptualized, and one of the models that mostly used is Hofstede's model $(1980,1997)$. He had identified that there is a difference between the consumer behaviour pattern of the East and the West due to the cultural differences. Social class has been related to consumer behaviour based on the classification of social class, which are upper-upper, lower-upper, upper-middle, lower-middle, upper-lower as well as lower-lower which related to income, source of income, education, occupation, and lastly, neighbourhood (Warner, 1949).

\section{Data and Method \\ Research Design}

The researcher would apply descriptive and explanatory research design with the help of the nature as well as objective of the study. The descriptive research design will help in analysing the impact of social media on consumer purchasing behaviour in Kuching in detail. The reason 
researcher has applied explanatory research design is to include the relationship between consideration factors and consumer purchasing behaviour in Kuching.

\section{Hypotheses}

The following figure explains the relationship between the factors and the consumer purchasing behaviour. There are four hypotheses have been developed and applied in this study.

\section{Personal Factor}

The null hypothesis is that personel factor has no influence on consumer purchasing behaviour, whereas the alternative hypothesis stated that personal factor has an influence on consumer purchasing behaviour. The hypotheses have been stated as below:

$\mathrm{H}_{0}$ : Personal factor has no influence on consumer purchasing behaviour.

$\mathrm{H}_{\mathrm{a}}$ : Personal factor has an influence on consumer purchasing behaviour.

Social Factor

The hypotheses for social factors have been proposed as below:

$\mathrm{H}_{0}$ : Social factor has no influence on consumer purchasing behaviour.

$\mathrm{H}_{\mathrm{a}}$ : Social factor has an influence on consumer purchasing behaviour.

Psychological Factor

The hypotheses for psychological factors are drawn as follow:

$\mathrm{H}_{0}$ : Psychological factor has no influence on consumer purchasing behaviour.

$\mathrm{H}_{\mathrm{a}}$ : Psychological factor has an influence on consumer purchasing behaviour.

Cultural Factor

The hypotheses for cultural factors are constructed as below:

$\mathrm{H}_{0}$ : Cultural factor has no influence on consumer purchasing behaviour.

$\mathrm{H}_{\mathrm{a}}$ : Cultural factor has an influence on consumer purchasing behaviour.

\section{Data Collection}

Primary and secondary data have been used to collect the data in this study. The researcher in this study will be using primary data which will be collected by questionnaire and give out to target respondents which is Social Media user in Kuching, Sarawak through Google form. The secondary data will be gathered through journals, websites, and online articles. The data will be focusing on the evaluation of impact of social media on purchasing behaviour of consumers in Kuching, Sarawak. The population in this study is comprised of consumers in Kuching, Sarawak. This study focuses on consumers who have experiences in purchasing via social media in Kuching. The population in Kuching, Sarawak is 570,407 as of at June 2019 (World Population Review, 2019). The total of the sample size will be 220 respondents which the questionnaire will be distributed to 220 respondents. This is because Hair et al. (2010) suggested the minimum sample size of 100 to 150 is required to ensure the stable Maximum Likelihood Estimation (MLE) solution.

\section{Pilot Test}

Pilot test has been implemented in this study to ensure the respondents are able to understand questions in questionnaires. According to Jacob and Furgerson (2012), pilot test 
ensure the questions prepared makes the respondents uncomfortable as well as determine the need for changing the questions. In addition, this test ensure the items in questionnaires meet the requirements of study. Also, this test help to verify the reliability alpha for each instrument used other than to achieve the objectives of the study. The pilot test was conducted before the actual study. This test involved 30 respondents to make sure that the actual respondents can understand the questions.

The result of reliability test for pilot test based on the questionnaire distributed by researcher are presented in Table 1. The sum of the value of Cronbach's Alpha for both independent variables as well as dependent variables is 0.893 . Hence, the data collected from the 30 respondents are reliable.

Table 1. Reliability Result of Pilot Test

\begin{tabular}{lcc}
\hline \multicolumn{1}{c}{ Variables } & Number of Items & Cronbach's Alpha \\
\hline IV 1 - Personal Factors & 5 & 0.704 \\
IV 2 - Social Factors & 10 & 0.714 \\
IV 3 - Psychological Factors & 20 & 0.773 \\
IV 4 - Cultural Factors & 9 & 0.846 \\
DV - Purchasing Behaviour & 14 & 0.836 \\
\hline \multicolumn{1}{c}{ Total } & $\mathbf{5 8}$ & $\mathbf{0 . 8 9 3}$
\end{tabular}

\section{Data Analysis}

The tool that researcher will use for data analysis is a 5 Point Likert Scale ( $1=$ Strongly Disagree, 2=Disagree, 3=Neutral, 4=Agree, 5=Strongly Agree).

\section{Frequency Analysis}

Frequency analysis is often used to study the frequency of letters or groups of letters in a cipher text that help to fracture classical cipher. In this study, however, frequency analysis is a descriptive statistical method that indicates the number of occurrences of each choice that has been chosen by the respondents. SPSS tool is used to calculate mean, median, and mode to help researcher interpret the results and come to conclusions.

\section{Descriptive Analysis}

The descriptive analysis was applied in the study to analyse the data obtained from respondents. This analysis applies the mean analysis to explain the information about the original data as well as provides the readers with clear picture to ensure a better understanding for the subject (Glass \& Hopkins, 1984). According to Borg and Gall (1989), mean analysis comprises of various variables and develops an exclusive message to readers to better understand the relationship between the variables.

\section{Pearson's Correlation Analysis}

Correlation is an approach that used to examine the relationship between the dependent variable, which is purchasing behaviour and independent variables, which are personal factors, social factors, psychological factors, and cultural factors) in this study. Table 2 showed the interpretation of the value of Pearson's Correlation Coefficient. The latter has been denoted by $r$ and designed as follows:

$$
-1 \leq \mathrm{r} \leq 1
$$


Table 2: Interpretation of the Value of Correlation Coefficient

\begin{tabular}{cc}
\hline Size of Correlation & Interpretation \\
$\pm 0.90-1.00$ & Very strong positive/negative correlation \\
$\pm 0.70-0.89$ & Strong positive/negative correlation \\
$\pm 0.40-0.69$ & Moderate positive/negative correlation \\
$\pm 0.10-0.39$ & Weak positive/negative correlation \\
$\pm 0.00-0.10$ & Little if any correlation
\end{tabular}

Source: Schober, Boer and Schwarte (2018)

\section{Multiple Regression Analysis}

In this study, the multiple regression analysis has been applied by researcher to evaluate the impact of social media on the purchasing behaviour as well as the most influential factors that affect the purchasing behaviour of consumers in Kuching, Sarawak. The formula of multiple regression is as follows:

Where,

$$
\mathrm{Y}=\alpha+\beta_{1} X_{1}+\beta_{2} X_{2}+\beta_{3} X_{3}+\beta_{4} X_{4}+e
$$

$\mathrm{Y} \quad=$ Purchasing Behaviour

$\alpha \quad=$ Constant

$\beta_{1}, \beta_{2}, \beta_{3}, \beta_{4}=$ Regression coefficient of variables

$\mathrm{X}_{1}, \mathrm{X}_{2}, \mathrm{X}_{3}, \mathrm{X}_{4}=$ Personal, social, psychological, and cultural factors

e $\quad$ error

\section{Results}

Table 2 below shows the summary of frequency analysis result which focuses on demographic profile of respondents. The results indicated there are total of 220 respondents answered the questionnaire, $28.6 \%$ of males and $71.4 \%$ of females. Based on the table below, 184 of the respondents are students, 29 of them are employed, 4 of them are self-employed, and there is one part-time student, one housewife, and one student who has been employed. Besides that, majority of respondents are within the age range of 18 to 23 years old (77.7\%), followed by 24 to 30 years old (20.0\%), 31 to 40 years old (1.4\%), under 18 years old as well as 51 to 60 years old, with similar percentage, 0.5 percent. 
Table 3. Summary of Frequency Analysis Result

\begin{tabular}{|c|c|c|}
\hline & Frequency & Percentage (\%) \\
\hline \multicolumn{3}{|c|}{ Gender } \\
\hline Male & 63 & 28.6 \\
\hline Female & 157 & 71.4 \\
\hline \multicolumn{3}{|c|}{ Age } \\
\hline Under 18 years old & 1 & 0.5 \\
\hline 18-23 years old & 171 & 77.7 \\
\hline 24-30 years old & 44 & 20.0 \\
\hline $31-40$ years old & 3 & 1.4 \\
\hline $51-60$ years old & 1 & 0.5 \\
\hline \multicolumn{3}{|c|}{ Race } \\
\hline Malay & 18 & 8.2 \\
\hline Bumiputera & 38 & 17.3 \\
\hline Chinese & 160 & 72.7 \\
\hline Indian & 4 & 1.8 \\
\hline \multicolumn{3}{|c|}{ Occupation } \\
\hline Student & 184 & 83.6 \\
\hline Self-employed & 4 & 1.8 \\
\hline Employed & 29 & 13.2 \\
\hline Part time student & 1 & 0.5 \\
\hline Student \& employed & 1 & 0.5 \\
\hline Housewife & 1 & 0.5 \\
\hline \multicolumn{3}{|c|}{ Marital Status } \\
\hline Single & 214 & 97.3 \\
\hline Married & 6 & 2.7 \\
\hline \multicolumn{3}{|c|}{ Educational Background } \\
\hline Primary school & 1 & 0.5 \\
\hline High school & 19 & 8.6 \\
\hline Vocational/Diploma & 20 & 9.1 \\
\hline Undergraduate & 173 & 78.6 \\
\hline Postgraduate & 7 & 3.2 \\
\hline \multicolumn{3}{|c|}{ Source of Income } \\
\hline Scholarship/Study loan & 126 & 57.3 \\
\hline Sponsored by parents & 55 & 25.0 \\
\hline Self-sponsored/Part time & 39 & 17.7 \\
\hline \multicolumn{3}{|c|}{ Monthly Income } \\
\hline Less than RM500 & 135 & 61.4 \\
\hline RM500-RM999 & 41 & 18.6 \\
\hline RM1000-RM1999 & 28 & 12.7 \\
\hline RM2000-RM2999 & 14 & 6.4 \\
\hline RM3000 and above & 2 & 0.9 \\
\hline
\end{tabular}


Table 3 below shows the data gathered and has been investigated for the usage of social media for respondents in Kuching, Sarawak. According to the table below, most of the respondents are using social media, which is close to 100 percent, for 219 respondents (99.5\%). At the same time, there is only 1 respondent who are not using social media which take up only 0.5 percent among the respondents. Besides, there are 200 of respondents access to social media daily $(90.9 \%), 13$ of them access weekly $(5.9 \%), 6$ of them access monthly (2.7\%), and 1 of them access to social media yearly (0.5\%). Lastly, the majority of respondents purchase on social media once in a few months, which are 116 of them $(52.7 \%)$; 49 of them purchase on social media monthly (22.3\%); and the number of respondents who purchase on social media every day and never are similar, which is $19(8.6 \%)$.

Table 4. Usage of Social Media

\begin{tabular}{ccc}
\hline & Frequency & Percentage (\%) \\
\hline Yes & Do you use Social Media? \\
No & 219 & 99.5 \\
\hline \multicolumn{3}{c}{ Frequency of access to Social Media } \\
\hline Daily & 200 & 0.5 \\
Weekly & 13 & 90.9 \\
Monthly & 6 & 5.9 \\
Yearly & 1 & 2.7 \\
\hline & & 0.5 \\
\hline Everyday & How often do you purchase on Social Media? \\
Weekly & 19 & 8.6 \\
Monthly & 17 & 7.7 \\
Once in a few months & 49 & 22.3 \\
Never & 116 & 52.7 \\
\hline
\end{tabular}

Based on the Table 4.8 as shown below, it can be concluded that most of the respondents seem to reach an agreement on the social factors with the value of average mean 3.49, which is the highest as compared to the other factors. Furthermore, psychological and cultural factors have been considered as the second highest factor with the average mean of 3.35. Personal factors, which has been agreed the least has only 1.71 of average mean value. Therefore, it is to be said that purchasing behaviour of respondents will be influence by social factors, which are the peers or families around them as well as reviews and information from social media while purchase on social media. 
Table 5. Summary of Descriptive Analysis

\begin{tabular}{cccc}
\hline Variable & Items & Average Mean & $\begin{array}{c}\text { Average Std. } \\
\text { Deviation }\end{array}$ \\
\hline $\begin{array}{c}\text { Dependent } \\
\text { Variable }\end{array}$ & Purchasing Behaviour & 3.19 & 0.900 \\
\hline & Personal Factors & 1.71 & 0.710 \\
$\begin{array}{c}\text { Independent } \\
\text { Variables }\end{array}$ & Social Factors & 3.49 & 0.935 \\
& Psychological Factors & 3.35 & 0.896 \\
& Cultural Factors & 3.35 & 0.948 \\
\hline
\end{tabular}

Based on Table 5 below, it is obvious that all the independent variables are having positive correlation with dependent variable, purchasing behaviour. However, psychological factors have the highest correlation coefficient value, which is 0.643 . The personal factors and purchasing behaviour with the correlation coefficient of 0.089 is not significant at the 0.01 level of significance. Nevertheless, the social factors, psychological factors as well as cultural factors are significant at 0.01 level of significance with the correlation coefficient of 0.481 , 0.643 , and 0.423 respectively.

Table 6. Summary Result and Interpretation of Pearson's Correlation Analysis

\begin{tabular}{cccc}
\hline Variables & $\begin{array}{c}\text { Correlation } \\
\text { Coefficient, } r\end{array}$ & Interpretation & Significant \\
\hline Personal Factors & 0.089 & Little if any correlation & Not significant \\
\hline Social Factors & $0.481^{* *}$ & $\begin{array}{c}\text { Moderate positive } \\
\text { correlation }\end{array}$ & Significant \\
\hline Psychological Factors & $0.643^{* *}$ & $\begin{array}{c}\text { Moderate positive } \\
\text { correlation }\end{array}$ & Significant \\
\hline Cultural Factors & $0.423^{* *}$ & $\begin{array}{c}\text { Moderate positive } \\
\text { correlation }\end{array}$ & Significant \\
\hline
\end{tabular}

Lastly, the multiple regression analysis was applied to determine the impact of social media on the purchasing behaviour. From Table 6, there is only one variable (psychological factors) which is statistically significant. As according to the result, the p-value of psychological factors is 0.000 , which is less than significance level of 0.01 , shows that it is statistically significant. Thus, it is concluded that psychological factors has impact on consumers purchasing behaviour. Meanwhile, the personal, social, and cultural factors are not statistically significant affect the consumers purchasing behaviour, with the $p$-value of $0.158,0.313$, and 0.725 respectively, which is greater than 0.05 . 
Table 7: Coefficients

\begin{tabular}{llccccc}
\hline \multirow{2}{*}{ Model } & \multicolumn{2}{c}{$\begin{array}{c}\text { Unstandardized } \\
\text { Coefficients }\end{array}$} & $\begin{array}{c}\text { Standardized } \\
\text { Coefficients }\end{array}$ & t & Sig. \\
\cline { 2 - 4 } & B & Std. Error & Beta & & \\
\hline \multirow{2}{*}{1} & (Constant) & .516 & .246 & & 2.093 & .038 \\
& Personal & .087 & .062 & .073 & 1.416 & .158 \\
& Social & .083 & .082 & .074 & 1.012 & .313 \\
& Psychological & .646 & .087 & .575 & 7.412 & .000 \\
& Cultural & .024 & .068 & .024 & .353 & .725 \\
\hline
\end{tabular}

a. Dependent Variable: Purchasing Behaviour

There was a study showed the consumers from Omani are mostly affected by informational and design factors while buying their preferred products through social media site (Ismael et al., 2014). Most of the previous studies were focused on purchasing decisions which related to consumer behaviour, where there was a result of a study in Bangkok showed that both demographic and marketing mix factors do not have significant relationship with the consumers' purchasing decisions, while the consumer behaviour has a significant relationship with the consumers' behaviour in pet retailing business (Chaipradermsak, 2007). Besides, there was a study found out cultural factors as the most influential in choosing online shopping while the most influential in choosing direct spending was psychological factors (Yolanda et al., 2017).

As compared to the findings of previous studies, this study found out that psychological factors as the most influential factor for purchasing behaviour of consumers in Kuching, Sarawak. This study is focus on consumer purchasing behaviour instead of purchasing decision that had been studied in previous studies. Also, it has been found out that all of the independent variables (personal factors, social factors, psychological factors, cultural factors) do affect the consumers purchasing behaviour, either little or moderate positive correlation.

\section{DISCUSSION}

Table 4.17: Summary of Hypotheses Result

\begin{tabular}{|c|c|c|}
\hline Hypotheses & Data Analysis Method & Results \\
\hline $\begin{array}{l}\text { H1: Personal factors has } \\
\text { an influence on consumer } \\
\text { purchasing behaviour. }\end{array}$ & $\begin{array}{c}\text { Multiple Regression } \\
\text { Analysis }\end{array}$ & $\begin{array}{c}\text { Not significant } \\
(p=0.158>0.05)\end{array}$ \\
\hline $\begin{array}{l}\text { H2: Social factors has an } \\
\text { influence on consumer } \\
\text { purchasing behaviour. }\end{array}$ & $\begin{array}{c}\text { Multiple Regression } \\
\text { Analysis }\end{array}$ & $\begin{array}{c}\text { Not significant } \\
(p=0.313>0.05)\end{array}$ \\
\hline $\begin{array}{l}\text { H3: Psychological factors } \\
\text { has an influence on } \\
\text { consumer purchasing } \\
\text { behaviour. }\end{array}$ & $\begin{array}{c}\text { Multiple Regression } \\
\text { Analysis }\end{array}$ & $\begin{array}{c}\text { Significant } \\
(p=0.000<0.05)\end{array}$ \\
\hline $\begin{array}{l}\text { H4: Cultural factors has } \\
\text { an influence on consumer } \\
\text { purchasing behaviour. }\end{array}$ & $\begin{array}{c}\text { Multiple Regression } \\
\text { Analysis }\end{array}$ & $\begin{array}{c}\text { Not significant } \\
(p=0.725>0.05)\end{array}$ \\
\hline
\end{tabular}

Personal Factors and Consumers Purchasing Behaviour 
Research Objective: To investigate the impact of personal factors on consumers purchasing behaviour in Kuching.

H1: Personal factors has an influence on consumer purchasing behaviour.

According to the results, the $p$-value of personal factors is 0.158 , which is greater than 0.05 , shows that the variable is statistically has no significant impact on consumers purchasing behaviour. Thus, the null hypothesis is accepted, which personal factors has no influence on consumer purchasing behaviour, and the alternative hypothesis is rejected.

Social Factors and Consumers Purchasing Behaviour

Research Objective: To investigate the impact of social factors on consumers purchasing behaviour in Kuching.

H1: Social factors has an influence on consumer purchasing behaviour.

The results indicated that social factors has no significant impact on consumers purchasing behaviour. This is due to the $p$-value of social factors is 0.313 , which is greater than the significance level of 0.05 . Therefore, the null hypothesis of social factors has no influence on consumer purchasing behaviour is accepted, as well as the alternative hypothesis is rejected.

Social Factors and Consumers Purchasing Behaviour

Research Objective: To investigate the impact of psychological factors on consumers purchasing behaviour in

Kuching,

$\mathrm{H1}$ : Psychological factors has an influence on consumer purchasing behaviour.

Based on the results, psychological factors has statistically significant impact on consumers purchasing behaviour due to the $p$-value of 0.000 , which is less than significance level of 0.01 . Thus, the null hypothesis is rejected, and the alternative hypothesis is accepted, which psychological factors has an influence on consumer purchasing behaviour.

Cultural Factors and Consumers Purchasing Behaviour

Research Objective: To investigate the impact of cultural factors on consumers purchasing behaviour in

Kuching,

H1: Cultural factors has an influence on consumer purchasing behaviour.

The result indicated that cultural factors is statistically not significant. The latter means that the cultural factors has no significant impact on consumer purchasing behaviour. This is because the $p$-value of cultural factors is 0.725 , which is greater than 0.05 . Hence, the null hypothesis is accepted and the alternative hypothesis is rejected, which cultural factors has no influence on consumer purchasing behaviour.

\section{Limitation of Study}

There are several limitations have been pointed out to help future researchers to run their study smoothly. One of the limitations of this study is that the sample size of the study is limited. In this study, there are 220 sets of questionnaires have been distributed to 
respondents. In order to evaluate the consumers purchasing behaviour accurately, it is desirable to have a large sample size. Besides, most of the respondents are Chinese, hence, future researchers could collect more of the data from different cultural background to enhance the results of the study.

\section{Conclusion}

In a nutshell, the objectives of this study are achieved. In this study, it is concluded that personal factors, social factors, psychological factors, and cultural factors are having positive relationship with dependent variable, which is consumers purchasing behaviour in Kuching, Sarawak. In addition, psychological factors are the most influential factor for purchasing behaviour of consumers in Kuching, Sarawak. As a result, the number of users who purchase on social media are increased from time to time, which businesses should fully apply the advantages of social media. Moreover, this study is beneficial for businesses in Kuching that operate on social media as it helps them to have a better understanding on consumers purchasing behaviour in Kuching, Sarawak. Hence, marketers should focus on the psychological factors due to the powerful influence on consumer purchasing behaviour. This recommendation can be carried out by marketers through observing the concerns of consumer by modifying their marketing strategies.

\section{References}

Ackland, R., \& Tanaka, K. (2015). Development impact of social media. Australian National University, Australia.

Albert. (2011). Shopping through social media: A study on consumer behaviour in Facebook's online shop page. STIKOM The London School of Public Relations Jakarta, Indonesia.

Asthana, H. S., \& Bhushan, B. (2007). Statistics for Social Sciences: With SPSS application. India: PHI Learning Pvt. Ltd.

Bashar, A., Ahmad, I., \& Wasiq, M. (2012). Effectiveness of social media as a marketing tool: An empirical study. International Journal of Marketing, Financial Services \& Management Resarch, 1(11), 88-99.

Bauer, R. A. (1960). Consumer behaviour as risk taking. Chicago: American Marketing Association.

Bharucha, J. (2018). Social media and young consumers behaviour. International Journal of Supply Chain Management, 7(6), 72-81.

Borg, W. R., \& Gall, M. D. (1989). Educational research: An introduction. $5^{\text {th }}$ edition. New York: Longman.

Cetina, I., Munthiu, M. C., \& Radulescu, V. (2012). Psychological and social factors that influence online consumer behaviour. Procedia - Social and Behavioural Science, 62, 184188.

Chaipradermsak, T. (2007). The influential factors on consumers' purchasing decision in Bangkok pet retailing business. (Unpublished master's thesis). Shinawatra University, Thailand.

Chen, C. P. (2012). Online group purchase behaviour in CC2B e-commerce: Understanding consumer motivations. Journal of Internet Commerce, 11(3), 254-270.

Chitharanjan, A. (2016). Analysing the impact of social media marketing and online advertisements on consumer behaviour. (Unpublished master's thesis). Dublin Business School, Ireland. 
Choudhury, A. (2009). Multiple regression analysis, Retrieved from https://explorable.com/multiple-regression-analysis

Constantinides, E. (2004). Influencing the online consumer's behaviour: The web experience. Internet Research, 14, 111-126.

Dhyani, S. (2017). A study on impact of social media on consumer buying behaviour. (Unpublished diploma's thesis). G.L. Bajaj Institute of Management and Research, India.

Dibb, S., Simkin, L., Pride, W. M., \& Ferrell, O. C. (1991). Marketing: Concepts and strategies. Boston, MA: Houghton Mifflin Harcourt.

Durmaz, Y. (2014). The influence of cultural factors on consumer buying behaviour and an application in Turkey. Global Journal of Management and Business Research: EMarketing, 14(1), 37-44.

Durrett, R. (2010). Probability: theory and examples. Cambridge University Press.

Dutta, S. (2010). Managing yourself: What's your personnel social media strategy? Retrieved from https://hbr.org/2010/11/managing-yourself-whats-your-personal-social-mediastrategy

Enis, B. M. (1974). Marketing principles: The management process. Journal of Marketing, 39, 121.

Fill, C. (2002). Marketing communications: Contexts, strategies, and applications. $3^{\text {rd }}$ edition. Harlow, Essex: Pearson Education Limited.

George, D., \& Mallery, P. (2003). SPSS for Windows step by step: A simple guide and reference. $4^{\text {th }}$ edition. Boston: Allyn \& Bacon.

Ghoshal, M. (2019). Social media as an effective tool to promote business - An empirical study. Global Journal of Management and Business Research, 1(1), 15-25.

Glass, G. V., \& Hopkins, K. D. (1984). Statistical methods in education and psychology. $2^{\text {nd }}$ edition. Englewood Cliffs, NJ: Prentice-Hall.

Hair, J. F., Black, W. C., \& Babin, B. J., \& Anderson, R. E. (2010). Multivariate Data Analysis. Seventh Edition. Prentice Hall, Upper Saddle River, New Jersey.

Hanna, W. (2013). Consumer behaviour: An applied approach (4th ed.). Kendall Hunt Publishing.

Ismael, S., Al-mukhaini, E., \& Al-Dhuhli, I. (2014). The impact of using social media on consumer buying behaviour: Case study of understanding the use of Social Media on consumers' buying decisions in Oman. Sultan Qaboos University, Oman.

Jacob, S. A., \& Furgerson, S. P. (2012). Writing interview protocols and conducting interviews: Tips for students new to the field of qualitative research. The Qualitative Report, 17(42), 1-10.

Lee, E. (2013). Impacts of social media on consumer behaviour: Decision making process. Turku University of Applied Sciences, Turku.

Malaysians Communications and Multimedia Commission. (2018). Internet users survey. Cyberjaya, Selangor: Malaysians Communications and Multimedia Commission.

Ramya, N., \& Ali, M. (2016). Factors affecting consumer buying behaviour. International Journal of Applied Research, 2(10), 76-80.

Schiffman, L. G., \& Kanuk, L. L. (2000). Consumer Behavior. $7^{\text {th }}$ edition. Wisconsin: Prentice Hall.

Schober, P., Boer, C., \& Schwarte, L. (2018). Correlation coefficients: Appropriate use and interpretation. Anesthesia \& Analgesia, 126(5), 1763-1768.

Smith, D. A., \& Rupp, T. W. (2003). Strategic online customer decision making: leveraging the transformational power of the Internet. Online Information Review, 27(6), 418-432. 
Toomey, A. C., \& Wysocki, A. F. (2009). Distinguishing between traditional and online retailing: Evaluating e-commerce with respect to the food system. University of Florida, Department of Food and Resource Economics.

Warner, W. L., Meeker, M., \& Eells, K. (1949). Social class in America: A manual of procedure for the measurement of social status. Chicago: Science Research Associates.

Woon, S. Y., \& Ong, C. H. (2018). The influence of advertising media towards consumer purchasing behaviour in the food and beverage industry in Malaysia. International Journal of Human Resource Studies, 8(2), 148-163.

Yolanda, A., Nurismilida, Herwinda, V. (2017). Affect of cultural factor on consumer behaviour in online shop. International Journal of Scientific \& Technology Research, 6(6), 287-292.

Zikmund, W. G., Babin, B. J., Carr, J. C., \& Griffin, M. (2013). Business research methods. $9^{\text {th }}$ edition. Mason, $\mathrm{OH}$ : South-Western. 